\title{
An Experimental Study of $\mathrm{NO}_{\mathrm{x}}$ Recycle in the NOXSO Flue Gas Cleanup Process
}

DOE/PC/91337--TI

DE92 01.1409

Quarterly Technical Progress Report No. 1

Submitted to

U.S. Department of Energy

Pittsburgh Energy Technology Center

September 18 through December 31, 1991

\section{DISCLAIMER}

Prepared by

NOXSO

CORPOORATION

P.O. Box 469

Library, PA 15129

This report was prepared as an account of work sponsored by an agency of the United States Government. Neither the United States Government nor any agency thereof, nor any of their Governmentes any warranty, express or implied, or assumes any legal liability or responsiemployees, makes any warranty, express or usefulness of any information, apparatus, product, or bility for the accuracy, completeness, or usefulness of any informe privately owned rights. Referprocess disclosed, or represents that its use would nol ins, or service by tracie name, tridemark, ence herein to any specific commercial product, process, or se imply its endorsement, recommanufacturer, or otherwise does not necessarily constitute or imply ils cndheref. The views mendation, or favoring by the United States Government or any state or reflect those of the and opinions of authors expressed herein do not and opinions Government or any agency thereof. 
TABLE OF CONTENTS

\subsection{Introduction \\ 2.0 Project Description \\ 3.0 Project Status \\ 4.0 Planned Activities \\ 5.0 Summary}

Prepared by

NOXSO

CORPORATIION

P.O. Box 469

Library, PA 15129 


\subsection{INTRODUCTION}

$\mathrm{NO}_{x}$ recycle is one part of the NOXSO process. In this process, $90 \%$ of the acid pollutants $\left(\mathrm{NO}_{\mathrm{x}}\right.$ and $\left.\mathrm{SO}_{2}\right)$ can be removed simultaneously by adsorption on the surface of a sorbent material. The sorbent is subsequently regenerated by heating and contacting the hot sorbent with a reducing gas followed by steam. The $\mathrm{NO}_{\mathrm{x}}$ is removed in the heating process, and the $\mathrm{SO}_{2}$ is removed by the chemical reaction of the reducing gas and steam. The $\mathrm{NO}_{\mathrm{x}}$ stream produced is returned to the combustion process with combustion air, which is called the $\mathrm{NO}_{\mathrm{x}}$ recycle. Thus, the $\mathrm{NO}_{x}$ is reduced in the flame.

The $\mathrm{NO}_{\mathrm{x}}$ recycle concept operates by means of two different mechanisms. The first relies on the thermodynamic and kinetic conditions in the flame. When $\mathrm{NO}_{\mathrm{x}}$ is fed to the coal combustor at concentrations greater than the equilibrium concentration, a portion of the recycled $\mathrm{NO}_{x}$ is reduced to $\mathrm{N}_{2}$ and $\mathrm{O}_{2}$ to approach the equilibrium concentrations (from high to equilibrium value). The second mechanism relies on the reducing nature of the combustor flame. The kinetic rate of NO formation also decreases due to the high initial recycled NO concentration. Free radicals generated at flame temperatures reacl with the $\mathrm{NO}_{\mathrm{x}}$ species reducing them to $\mathrm{N}_{2}$ and $\mathrm{H}_{2} \mathrm{O}$ or $\mathrm{CO}_{2}$. Therefore, reaction equilibrium and the reducing atmosphere in the flame both serve to destroy recycled $\mathrm{NO}_{\mathrm{x}}$ species.

$\mathrm{NO}_{x}$ recycle will be implemented at the full-scale commercial demonstration plant at Niles. The concept of $\mathrm{NO}_{\mathrm{x}}$ recycle has been tested previously at PETC using a $500 \mathrm{lb} / \mathrm{hr}$ coal combustor used for the $3 / 4 \mathrm{MW}$ tests and also using a tunnel furnace capable of being fired with a variety of fuels including gas, fuel oil, coal, and coal-water mixtures. The results were very promising and demonstrated the destruction of $\mathrm{NO}_{\mathrm{x}}$ compounds when fed to combustion system. The data also indicate that the extent of $\mathrm{NO}_{\mathrm{x}}$ reduction is determined by the location of the $\mathrm{NO}_{\mathrm{x}}$ injection and the combustor design.

This current project is pilot-scale testing of $\mathrm{NO}_{\mathrm{x}}$ recycle. The objective is to provide further fundamental understanding and useful information for its implementation at the Niles 
station. A Babcock \& Wilcox's 6 million Btu/hr Small Boiler Simulator (SBS) (see Figures 1 and 2) has been chosen to perform the tests. The SBS is the same type of cyclone furnace as that at Niles and simulates a large cyclone unit very well (see Table 1).

The project involves conducting a series of tests which include injecting $\mathrm{NO}, \mathrm{NO}_{2}, \mathrm{~N}_{2} \mathrm{O}$, and simulated $\mathrm{NO}_{\mathbf{x}}$ recycle stream respectively. The work performed during this reporting period focused on the site preparation, shakedown tests, and baseline tests. The shakedown testing of NO injection into the primary air stream alone and the secondary air stream alone showed promising results. A large amount of NO injected into furnace was destroyed, especially when the NO was injected into the primary air duct. However, the measuring instrumentation needs to be improved to give accurate data.

\subsection{PROJECT DESCRIPTION}

In order to provide further fundamental understanding and useful information for its implementation at the Niles station, the following four tasks have been defined to be performed in this project:

Task 1: Project management and reporting. This includes overall management of the project, preparation of monthly reports, preparation of draft and final project work plan, supervision of tests performed by $\mathrm{B} \& \mathrm{~W}$, and final report preparation.

Task 2: Experimental Testing. This has been subcontracted to B\&W. It involves site preparation and testing. The tests consist of shakedown, baseline, simulated NO recycle, simulated $\mathrm{NO}_{2} / \mathrm{N}_{2} \mathrm{O}$ recycle, and novel concept tests. The $\mathrm{NO}, \mathrm{NO}_{2}$ and $\mathrm{N}_{2} \mathrm{O}$ will be injected separately to investigate their effects on the $\mathrm{NO}_{\mathrm{x}}$ destruction in the furnace. The injection of simulated $\mathrm{NO}_{\mathrm{x}}$ recycle stream will also be tested. The injection location will be in the primary air alone, secondary air alone, and both primary air and secondary air together. The parameters varied during the tests are furnace load, outlet oxygen concentration, and the amount of injected gases which are multiples of the baseline $\mathrm{NO}_{\mathbf{x}}$ production levels. 
Task 3: Data Analysis. The testing data will be compared with previous results of $\mathrm{NO}_{\mathrm{x}}$ recycle tests at PETC and recommendations for burner operation and $\mathrm{NO}_{\mathrm{x}}$ recycle will be prepared.

Task 4: Comparison of B\&W's pilot scale boiler to Ohio Edison's commercial boiler at Niles, Ohio. The end result of this task will be a comparison of the two units and suggested conditions for the $\mathrm{NO}_{\mathrm{x}}$ recycle tests.

\subsection{PROJECT STATUS}

\section{Management and Report:}

i. Overall Management and Monthly Reporting: The project management team has been established. Monthly management reports, along with accounting and billing of project costs were prepared and submitted to DOE on time.

ii. Work Plan Preparation: A final project plan, which has been prepared by NOXSO and its subcontractor (B\&W) and reviewed by Ohio Edison, has been submitted to DOE.

iii. Supervision of Testing: A member of the NOXSO staff was on-site during the tests conducted in Task 2 to monitor the operation of the test unit, examine test procedures, and insure that the necessary data was collected.

\section{Experimental Testing: (Subcontracted to B\&W)}

i. Management and Reporting: The subcontract agreement between NOXSO and B\&W was reviewed and signed. A project kick-off meeting was held with NOXSO and B\&W personnel in attendance at Alliance $B \& W$ research center to review the contract workscope, team responsibilities, and projected test schedule. A safety meeting was held with $\mathrm{B} \& \mathrm{~W}$ personnel to discuss the procedures that need to be followed for the NO injection and a written report was 
made by $B \& W$ to document the hazards involved and steps to follow for any possible leaks of the injection gas. A NOXSO member was on-site to supervise the tests. NOXSO and B\&W had a few meetings and regular phone conversations to discuss concerns that arose during the shakedown and initial NO injection testing.

ii. Site Preparation: B\&W has installed a NO gas injection system capable of adding NO gas to the combustion primary air ducting and/or secondary air ducting and an inlet $\mathrm{NO} / \mathrm{NO}_{\mathrm{x}}$ sampling system. As shown in Figure 3, pure NO gas from the gas cylinder goes through a rotameter and is injected into the combustion air duct a short distance from the furnace. The injector was designed to release NO countercurrently to the incoming combustion air. The goal is to maximize the mixing of the injected gas in the air stream. The sampling probes for the inlet $\mathrm{NO}$ and $\mathrm{NO}_{\mathrm{x}}$ measurement are installed downstream of the injection location and before the cyclone. The sample gas goes through an ice bath to condense the water and is analyzed by the continuous $\mathrm{NO} / \mathrm{NO}_{\mathrm{x}}$ analyzers. The stack gas sampling system already exists. The data acquisition program was slightly modified to incorporate on-line determination of the reduction efficiency of the NO injection.

An Ohio \#5 seam coal was selected as a representative coal at the Niles Plant and delivered to B\&W. The analyses of the coal were completed by $\mathrm{B} \& \mathrm{~W}$. These analyses included Proximate, Ultimate, Btu, Ash Fusion (reducing and oxidizing conditions), and the Major Constituent and Alkali content of the ash. The data obtained from the Major Constituent and Alkali tests were used to calculate the $T_{250}$ temperature of the ash. This is the temperature at which the ash has a viscosity of 250 poise. This information gives a close indication of the slag tapping performance that can be expected. The temperature was calculated to be $2353^{\circ} \mathrm{F}$.

iii. Testing: Shakedown of the facility began the end of November. The facility was started and run for approximately 4 hours with coal. The slag tapping performance of the coal was observed and found to be acceptable. After solving a few minor problems discovered during the shakedown test, the baseline testing followed. This includes running at 3 different loads and 3 different excess $\mathrm{O}_{2}$ concentrations to establish the baseline stack $\mathrm{NO}_{\mathrm{x}}$ levels. 
A shakedown of the facility for NO injection testing began the second week of December. Three tests with NO injected into the primary air ducting and two tests with NO injected into the secondary air ducting were performed. The furnace load and outlet $\mathrm{O}_{2}$ concentration were constant while the injected NO concentration was varied. The test results indicated that large amounts of injected NO were destroyed in the furnace, especially when NO was injected at the primary air ducting. However, accurate data could not be issued due to the problems in the measurement of inlet $\mathrm{NO}$ concentrations. The readings of the $\mathrm{NO} / \mathrm{NO}_{\mathrm{x}}$ analyzer showed a sizable difference between the $\mathrm{NO}$ and $\mathrm{NO}_{\mathrm{x}}$ concentrations going into the cyclone. This difference was thought to be due to conversion of $\mathrm{NO}$ to $\mathrm{NO}_{2}$ at the conditions of high $\mathrm{O}_{2}$ and NO concentrations and low temperature. Additional tests were initiated to investigate why these differences in the readings were being seen. The analysis of the data is in process. The information from these tests indicated that some amount of $\mathrm{NO}_{\mathrm{x}}$ (specially $\mathrm{NO}_{2}$ ) was scrubbed by the condensed water in the ice bath of the sample line. Therefore, the injected $\mathrm{NO}_{\mathrm{x}}$ measured by the $\mathrm{NO} / \mathrm{NO}_{\mathrm{x}}$ analyzer is less than the actually injected amounts, and the corresponding $\mathrm{NO}_{\mathrm{x}}$ destruction efficiency calculated using this inaccurate data is lower which can only be used to indicate a minimum number.

Testing ended the third week of December due to facility commitments to other projects and will resume the middle of February.

iii. Data Analysis and Engineering Support: The data obtained from the baseline tests were compiled and evaluated by B\&W. A comparison was made between the data obtained from the computer data acquisition system and the panel board data taken manually. These values were found to match.

\section{Data Analysis:}

All the data from the shakedown and baseline tests have been analyzed. The preliminary data from the baseline tests are shown in Table 2. The furnace load varies from 4.1 to 5.9 $\mathrm{MBtu}$ and the excess $\mathrm{O}_{2}$ concentration varies from $1.9 \%$ to $4.3 \%$. The stack $\mathrm{NO}_{x}$ concentration 
ranges from 955 to $1199 \mathrm{ppm}$. This $\mathrm{NO}_{\mathrm{x}}$ level is higher than that at the Niles plant, which is around $800 \mathrm{ppm}$. It seems that the average stack $\mathrm{NO}_{\mathrm{x}}$ concentration increases with the furnace load. However, the change of the stack $\mathrm{NO}_{\mathbf{x}}$ concentration is very small when the excess $\mathrm{O}_{2}$ oxygen level changes and there is no obvious trend between those two parameters.

As mentioned above, due to the problem in the measurement, no accurate data related to $\mathrm{NO}_{\mathrm{x}}$ destruction efficiency can be issued from the NO injection shakedown tests.

\section{Comparison of B\&W Research Apparatus to Ohio Edison's Boiler in Niles, Ohio:}

A meeting was held at the Alliance Research Center between NOXSO, B\&W, and Ohio Edison. Some concerns of Ohio Edison were voiced about the differences between B\&W's facility and Ohio Edison's plant. Afterwards, NOXSO and Ohio Edison had a meeting at Niles to further review the work plan and discuss the integration of the $\mathrm{NO}_{\mathrm{x}}$ recycle at Niles.

\subsection{PLANNED ACTIVITIES}

Efforts will be made to ensure accurate measurement of injected $\mathrm{NO}$ and $\mathrm{NO}_{\mathrm{x}}$ destruction efficiency. The rotameter readings in the NO injection line (see Figure 3) will be calibrated and used to record the injected NO flow rate. A heated sample line and Perma-Pure membrane dryer or capillary heater will be used, and the ice bath will be removed from the sample line to avoid the conversion of $\mathrm{NO}$ to $\mathrm{NO}_{2}$, the condensing of the water, and the total $\mathrm{NO}_{\mathrm{x}}$ loss in the sampling system.

The order of the testing series will be changed. In order to check out the modified sampling system, the separate $\mathrm{NO}_{2}$ injection tests will be conducted earlier than planned. The comparison of separate $\mathrm{NO}$ and $\mathrm{NO}_{2}$ injections will also be made to investigate the relative effects of $\mathrm{NO}$ and $\mathrm{NO}_{2}$ on the $\mathrm{NO}_{\mathrm{x}}$ destruction in the furnace. Testing will resume in February and continue until all the workscope in the work plan is completed. 


\subsection{SUMMARY}

This project was awarded on September 18. Afterwards, a final project plan was submitted to the DOE. Monthly management reports, along with accounting and billing of project costs were prepared and submitted on time. The subcontract agreement between NOXSO and $\mathrm{B} \& \mathrm{~W}$ was also reviewed and signed. Both NOXSO and $\mathrm{B} \& \mathrm{~W}$ have established the project management team and have close communication on the ongoing events.

During the current reporting time (from October to December), efforts focused on site preparation, shakedown testing and baseline testing. The analysis of the coal, which is a representative coal at the Niles Plant, has been completed. The NO injection system and sampling system have been installed. Baseline stack $\mathrm{NO}_{x}$ levels have been established from the baseline tests. A shakedown of the facility for the NO injection testing has been performed. Varied amounts of NO were injected into the furnace from the primary air stream and the secondary air stream. The test results indicated that large amounts of injected NO were destroyed in the furnace, especially when NO was injected at the primary air stream. However, the instrumentation of the measurement of $\mathrm{NO}$ and $\mathrm{NO}_{x}$ concentrations need be improved to give accurate data. 


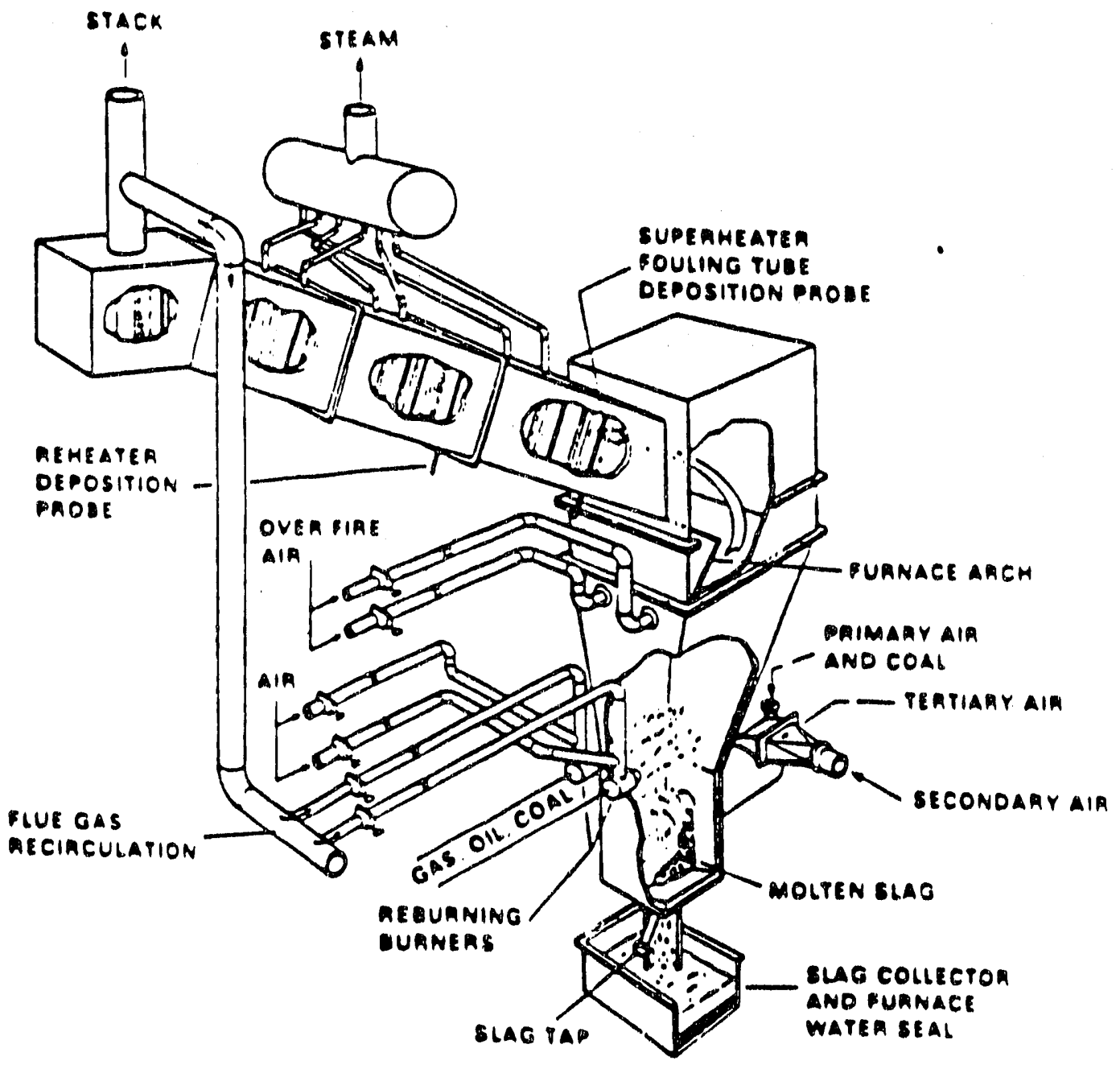

Figure 1. Small Boiler Simulator (S3S) Schematic 


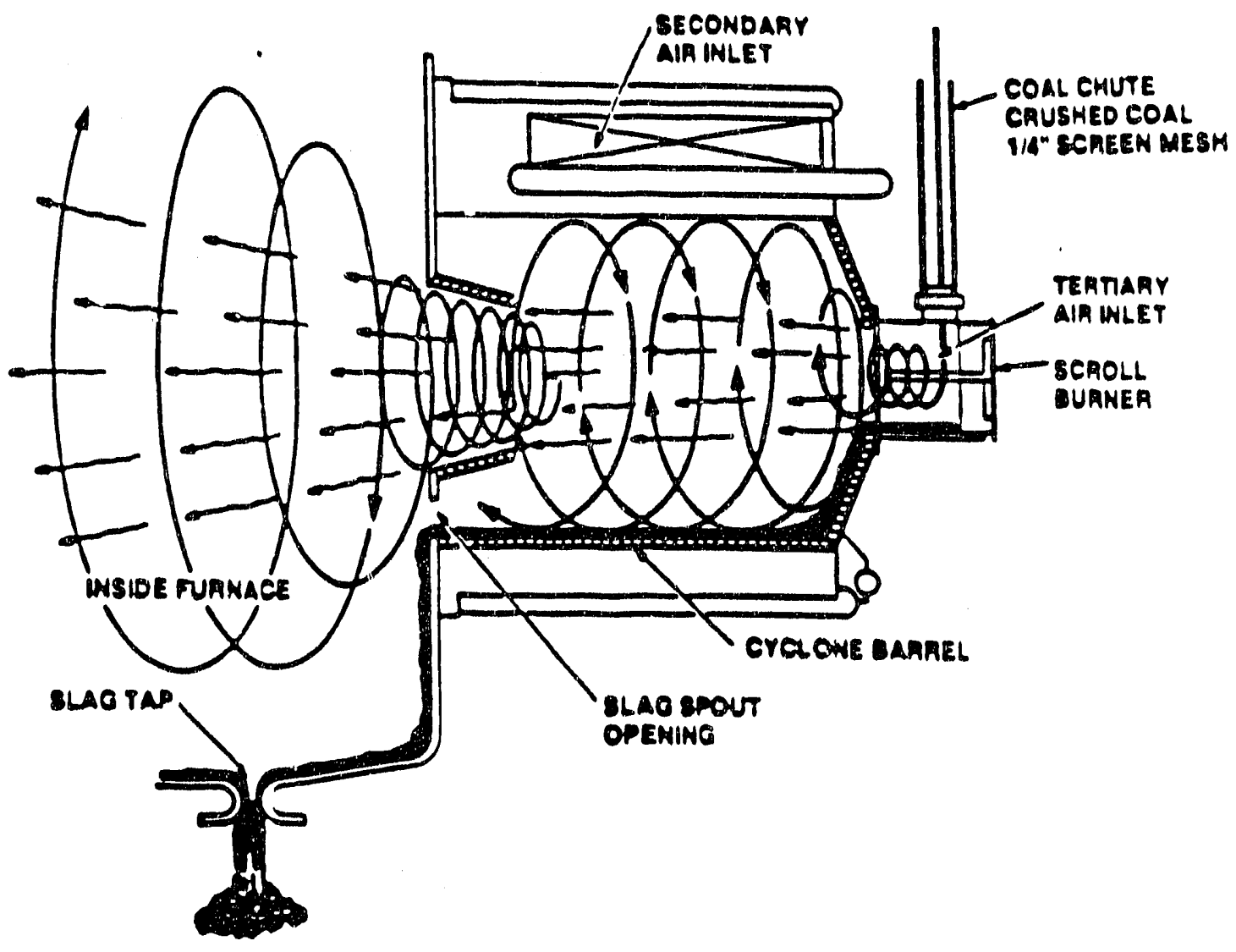

Figure 2. Cyclone Furnace 


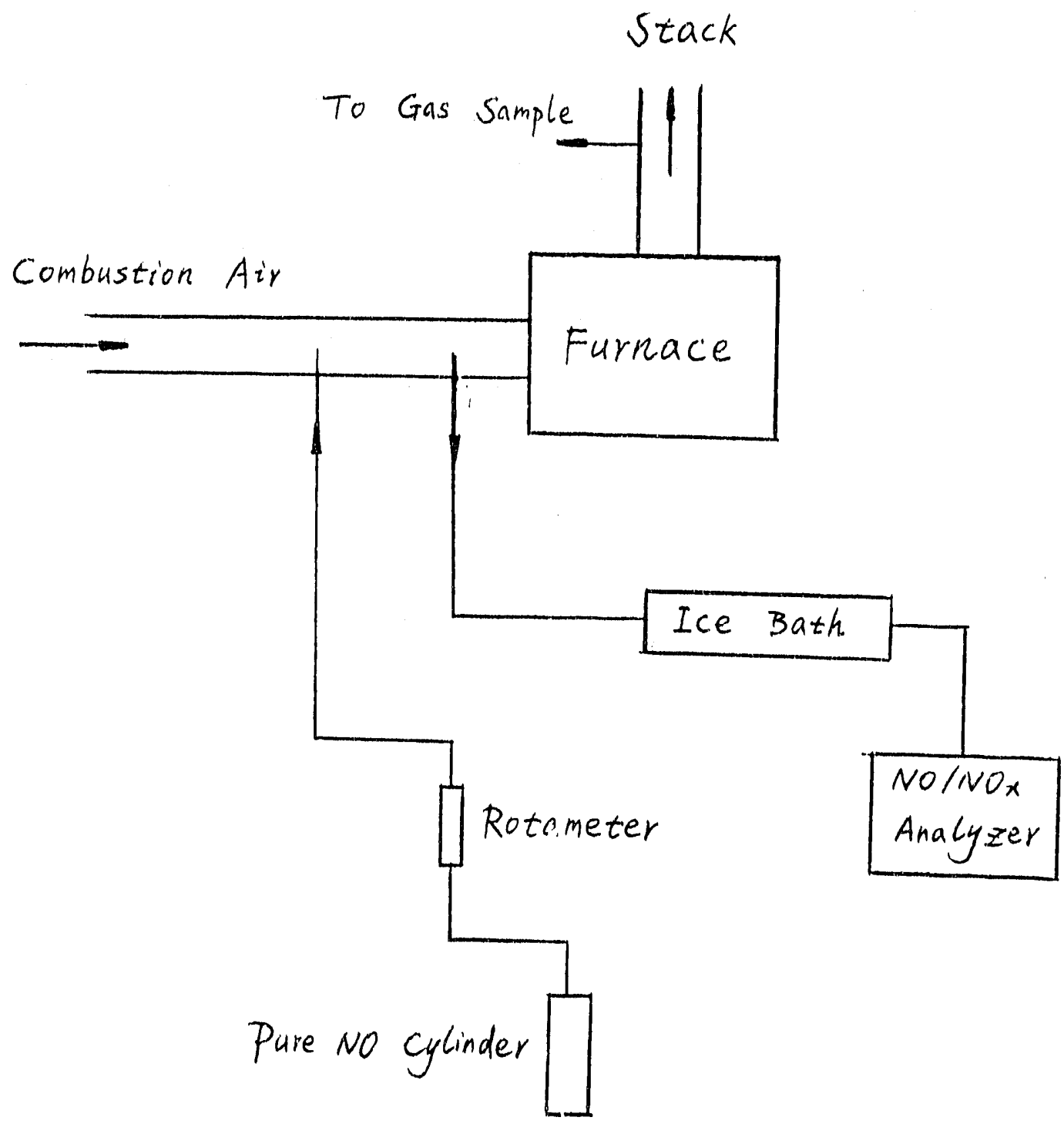

Figure 3. Schematic of NO injection and Sampling Systems 


\begin{tabular}{|c|c|c|}
\hline & SBS & $\begin{array}{c}\text { Typical } \\
\text { Cyclone-Fired Boilers }\end{array}$ \\
\hline Cyclone Temperature & $>3000^{\circ} \mathrm{F}$ & $>3000^{\circ} \mathrm{F}$ \\
\hline Resident Time & $1.4 \mathrm{sec}$. at full load & $0.7-2 \mathrm{sec}$ \\
\hline Furnace Exit Gas Temperature & $2265^{\circ} \mathrm{F}$ & $2200^{\circ}-2350^{\circ} \mathrm{F}$ \\
\hline $\mathrm{NO}_{x}$ Level & 900-1200 PPM & $600-1400$ PPM \\
\hline Ash Retention & $80-85 \%$ & $60-80 \%$ \\
\hline Unburned Carbon & $<1 \%$ in Ash & $1-20 \%$ \\
\hline $\begin{array}{l}\text { Ash Particle Size } \\
\text { (MMD; Bahco) }\end{array}$ & 6-8 microns & 6-11 microns \\
\hline
\end{tabular}




\begin{tabular}{||c|c|c|c||}
\hline \multicolumn{4}{|c|}{ Table 2. Baseline Testing Data } \\
\hline \hline Test ID & $\begin{array}{c}\text { Total Load } \\
(\mathrm{MBtu} / \mathrm{hr})\end{array}$ & $\begin{array}{c}\text { Excess } \mathrm{O}_{2} \\
(\%)\end{array}$ & $\begin{array}{c}\mathrm{NO}_{\mathrm{x}} \\
(\mathrm{ppmV})\end{array}$ \\
\hline $12024 \mathrm{~b} 2$ & 4.30 & 1.93 & 1006.7 \\
\hline $12024 \mathrm{~b} 3$ & 4.13 & 2.90 & 955.4 \\
\hline $12024 \mathrm{~b} 4$ & 4.11 & 3.81 & 987.4 \\
\hline $12045 \mathrm{~b} 2$ & 5.15 & 2.05 & 1025.1 \\
\hline $12045 \mathrm{~b} 3$ & 5.14 & 2.89 & 1076.9 \\
\hline $12045 \mathrm{~b} 4$ & 5.02 & 4.25 & 1042.1 \\
\hline $11276 \mathrm{~b} 1$ & 5.82 & 1.62 & 1199.5 \\
\hline $11276 \mathrm{~b} 2$ & 5.74 & 2.69 & 1149.2 \\
\hline $11276 \mathrm{~b} 3$ & 5.91 & 3.49 & 1089.2 \\
\hline $12196 \mathrm{~b} 2$ & 5.79 & 2.52 & 1082.7 \\
\hline $12196 \mathrm{~b} 3$ & 5.68 & 2.89 & 1110.6 \\
\hline $12196 \mathrm{~b} 4$ & 5.73 & 3.83 & 1066.2 \\
\hline
\end{tabular}



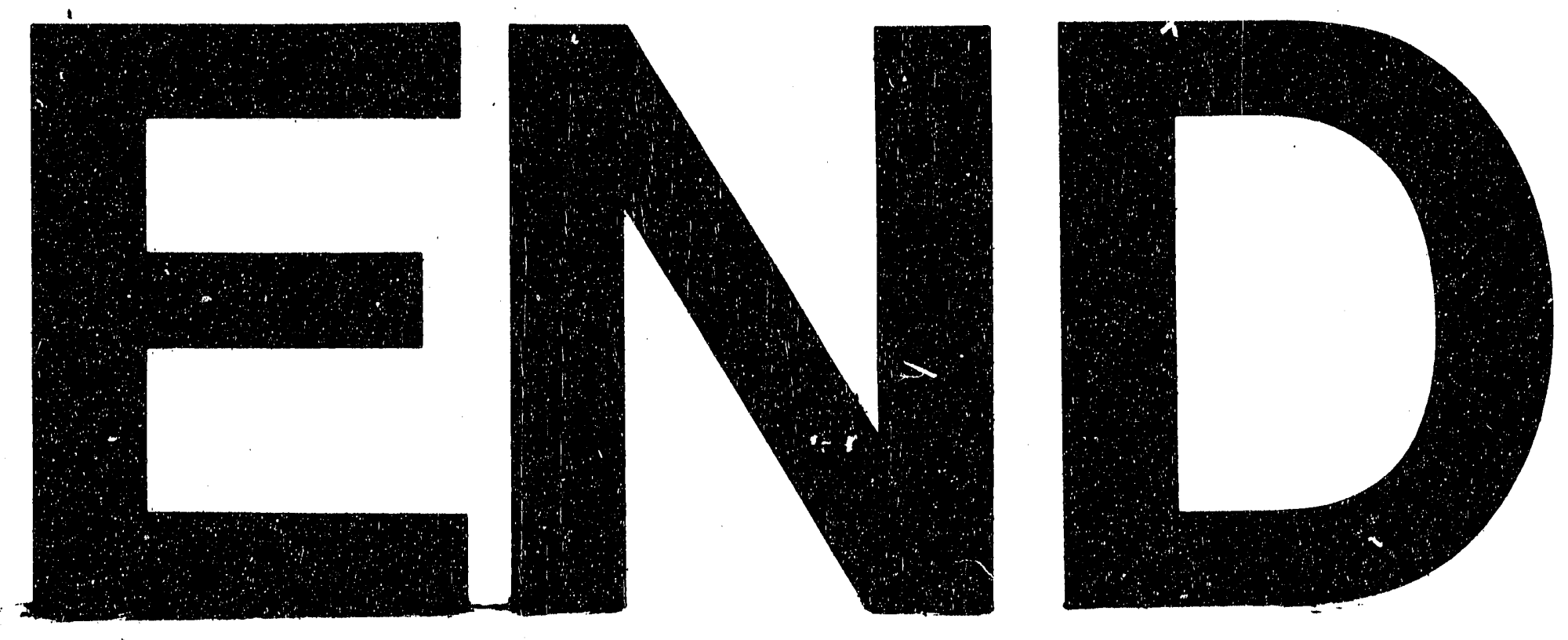

E
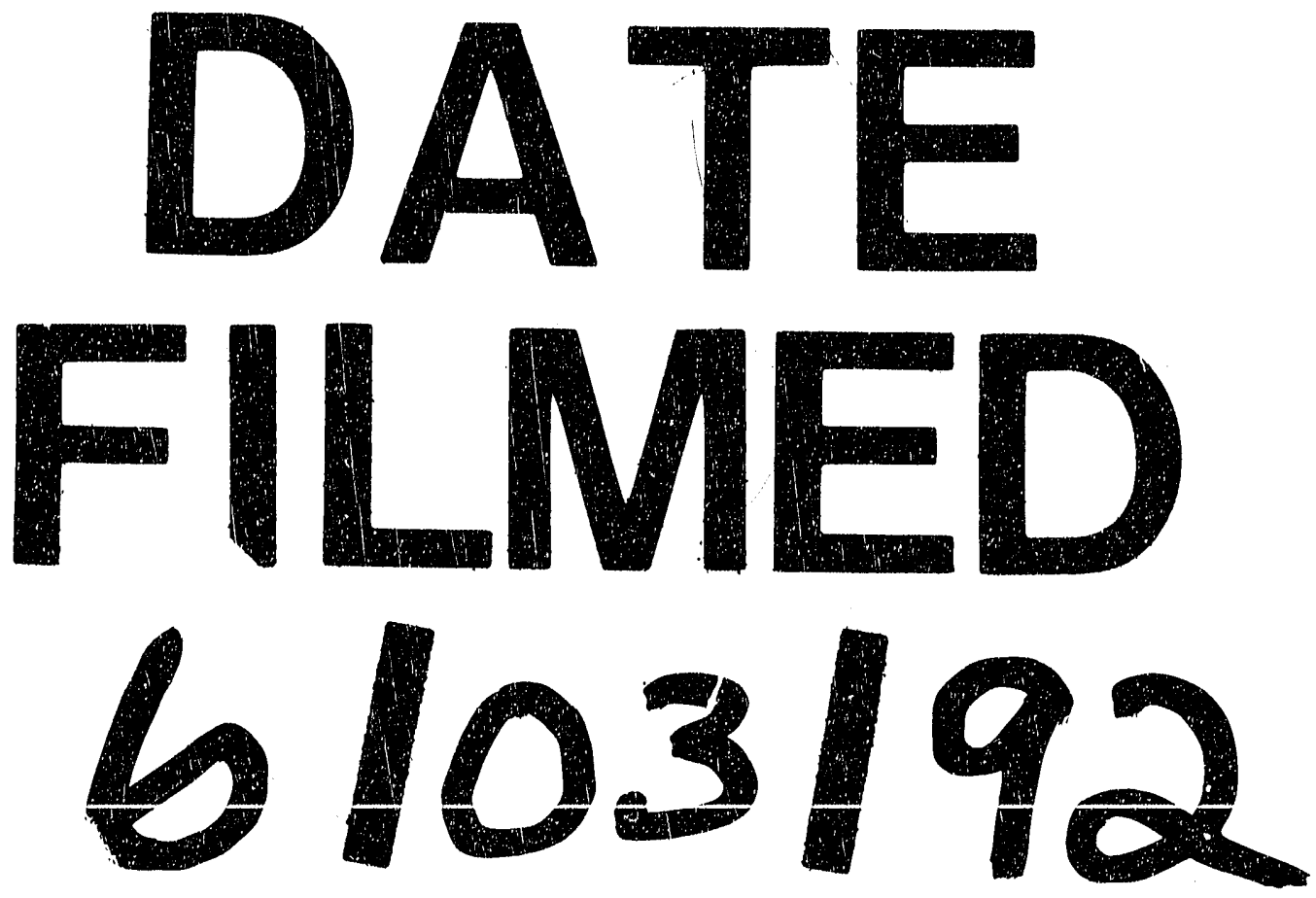
